\title{
DISCUSSION
}

\section{The strength and dilatancy of sands}

\author{
M. D. BOLTON (1986). Géotechnique 36, No. 1, 6578
}

Dr J. R. F. Arthur, University College London

The Author's reply to Tatsuoka's discussion contribution (Bolton, 1987) misinterprets the paper written by Wong \& Arthur (1985). This paper showed that large changes in straininduced anisotropy did not affect the drained strength anisotropy due to deposition (the inherent anisotropy). Indeed this is the sole justification for retaining the term inherent anisotropy. However, induced anisotropy is shown to have large effects on stiffness and volume changes during drained loading so that considerable initial compression can occur even in a dense sand. This will reduce the undrained strength through porewater pressure generation. When shearing looser sand in undrained conditions it will not always he possible to attain the obliquity of $\phi_{\mathrm{cv}}$.

\section{REFERENCES}

Bolton, M. D. (1987). Discussion on The strength and dilatancy of sands. Géotechnique 37, No. 2, 219-226.

Wong, R. K. S. \& Arthur, J. R. F. (1985). Induced and inherent anisotropy in sand. Géotechnique 35 , No. 4, $471-481$. 